УДК 159.923 .2

DOI https://doi.org/10.32838/2709-3093/2021.3/02

Артюхіна Н.В.

Одеський національний університет імені I.I. Мечникова

Сімовоник А.I.

Одеський національний університет імені I.I. Мечникова

\title{
ВПЛИВ НАВЧАЛЬНОГО КУРСУ 3 АРТ-ТЕРАПІЇ НА ПІДВИЩЕННЯ КРЕАТИВНОСТІ ТА САМОУСВІДОМЛЕННЯ ВЛАСНИХ ПСИХОЛОГІЧНИХ ОСОБЛИВОСТЕЙ У СТУДЕНТІВ-ПСИХОЛОГІВ
}

\begin{abstract}
У статті представлено дослідження впливу навчального курсу з арт-терапї на підвищення креативності та самоусвідомлення психологічних особливостей у студентів-психологів як суб'єктів власної життєтворчості. Вказується, що наразі все більш актуальними стають завдання саме розвитку особистості, підвищення самоусвідомлення, моральної відповідальності та активації його власного життетворчого потенціалу. У зв'язку з иим підготовка майбутнього психолога повинна бути спрямована не тільки на здобуття певної професійної кваліфікації за відповідним напрямом, а й на покращення соціалізаиії сучасного студента та гармонізацію його взаємодії із самим собою та реальною дійсністю. Також вказується, що на етапі вищої психологічної освіти все більще зростає інтерес до таких навчальних технологій і методів, які можуть здійснювати безпечний та позитивний вплив на підтримування психічного здоров'я та особистісний розвиток студентів, а надалі стати ефективними інструментами їхньої професійної діяльності. Підкреслюється, щзо до таких навчальних технологій можна віднести арт-терапію, в процесі вивчання якої студенти набувають необхідного теоретико-практичного досвіду з питань безпечного, позитивного впливу на психічне й соціальне здоров'я особистості, а також з питань психологічної корекції емоційних станів й активації внутрішнього творчого потенціалу людини за допомогою мистецтва. Вказується, щчо вивчення теорії з арт-терапії, практичне опрачювання вправ у навчальній групі та самостійне опращьовування арт-терапевтичних засобів саморегуляиії сприяють не тільки покращенню психоемоиійного стану студентів та підвищенню їхнього власного самоусвідомлення, але й виливають на розвиток творчих здібностей, на більш вільне саморозкриття, на придбання навичок продуктивної міжособистісної взаємодії й на усвідомлення можливості керувати своїми психічними процесами й станами, як свідомих суб'єктів власної життєтворчості. Саме формування особистості, здатної до власної життєтворчості, є основним завданням сьогодні, що постає перед закладами вищої освіти, які здійснюють професійну підготовку майбутніх психологів-фахівиів.
\end{abstract}

Ключові слова: особистість, арт-терапія, навчання, самоусвідомлення, креативність, суб'єкт власної життетворчості, самоактуалізаиія.

Постановка проблеми. В умовах відсутності стабільності та постійних змін у суспільстві завдання професійної підготовки й розвитку особистості майбутнього фахівця-психолога у періоді ранньої дорослості набувають особливого значення. Основним результатом психологічного розвитку особистості в цьому віці є інтелектуальна зрілість та закладені основи особистісної й соціальної зрілості.

Отже, підготовка майбутнього психолога повинна бути спрямована не тільки на здобуття певної професійної кваліфікації за відповідним напрямом, а й на покращення соціалізації сучасного студента та гармонізацію його взаємодії з реальною дійсністю. Все більш актуальними стають завдання саме розвитку його особистості, підвищення самоусвідомлення, моральної відповідальності та активації його власного життєтворчого потенціалу. Тому наразі на етапі вищої психологічної освіти все більш зростає інтерес до таких навчальних технологій i методів, які можуть в процесі навчання здійснювати безпечний та позитивний вплив на підтримування психічного здоров'я та особистісний розвиток студентів, а надалі стати ефективними інструментами їхньої професійної діяльності. Саме до таких навчальних технологій можна віднести арт-терапію, в процесі вивчання якої студенти набувають 
необхідного теоретико-практичного досвіду 3 питань безпечного, позитивного впливу на психічне й соціальне здоров'я особистості, а також 3 питань психологічної корекції емоційних станів й активації внутрішнього творчого потенціалу людини за допомогою мистецтва. У феномені творчості закладена життєстверджуюча, зорієнтована на майбутнє енергія [5]. Власне переживання та усвідомлення отриманого досвіду, винесеного 3 курсу арт-терапії, на нашу думку, сприяє не тільки збільшенню креативності студентів, а й більш адекватному оцінюванню себе, особистих властивостей, що є необхідними умовами для формування майбутнього психолога-фахівця.

Аналіз останніх досліджень і публікацій. Аналіз досліджень і публікацій, присвячених арт-терапії та іiї впливу на особистість, привертає увагу своєю багатогранністю. Методичні аспекти арт-терапії доволі грунтовно розглянуті в наукових публікаціях зарубіжних арт-терапевтів (А. Хілл, Дж. Морено, Х. Ландгартен, М. Бетенскі, Е. Крамер, М. Лібман, М. Наумбург, Дж. Кампбелл, Дж. Келлог, А. Лоуен, М. Андерсен-Уорен та інших.) Загальні аспекти арт-терапії представлені у роботах таких зарубіжних дослідників, як К. Рудестам, Л. Аметова, Л. Белозьорова, Б. Карвасарський, М. Кисельова, І. Бирюкова, І. Бреусенко-Кузнєцов, О. Будза, М. Бурно, І. Вачков, В. Нікітін, Ю. Гундертайло, Т. Колошина, Е. Келліш та інші [3]. Актуальність і застосування арттехнологій в освітньому процесі, а також шляхи активізації внутрішніх ресурсів та потенціалу особистості за допомогою арт-терапії розглядали у своїх роботах такі автори, як О. Копитін, В. Кокоренко, Л. Лебедєва, Т. Зінкевич-Свстигнєєва, Н. Артюхіна, О. Вознесенська, Л. Волкова, Л. Мова, С. Пінчук, Г. Побережна, О. Сорока, В. Шевченко О. Лобарец, Н. Полякова, І. Садова, В. Саранцева, О. Тараріна, А. Чупріков, Т. Яценко, Л. Подкоритова, О. Назаренко та інші [2]. Основна думка, що проходить червоною ниткою через їхні дослідження, зводиться до того, що людина у процесі творчої діяльності, зокрема у процесі арт-терапії, задовольняє свою найголовнішу фундаментальну потребу - потребу в самоактуалізації. Центральною фігурою в арт-терапевтичному процесі є особистість, яка прагне до саморозвитку й розширення діапазону своїх творчих можливостей. Отже, творчий процес зцілює і водночас $є$ таким, що глибоко перетворює [1].

Нині навчання з арт-терапії для студентів-психологів одночасно є засвоєнням технології психічної гармонізації й розвитку людини, засобом розв'язання внутрішніх конфліктів, технологією активізації творчих ресурсів і поширення діапазону самоусвідомлення й саморегуляції. Своєю чергою наявність потужного творчого потенціалу здатна надалі розширити поле самореалізації майбутніх психологів-фахівців.

Постановка завдання. Навчально-практичний курс 3 арт-терапії є спрямованим на підвищення самоусвідомлення у студентів щодо їх власних психологічних особливостей, на обізнаність щодо роботи 3 власними емоціями й станами на шляху «оволодіння ними», що, за словами Л.С. Виготського, $є$ метою розвитку особистості, а також на розвиток креативності у студентів під час самореалізації їхніх особистісних потенціалів. Розвиток навичок вільного самовираження приводить до того, що студенти починають свідомо й активно сприймати себе та інших, в них відкривається здатність щось міняти в собі, змінювати щось у світі, а не тільки пристосовуватися до нього [4]. Цей досвід $є$ дуже важливим вже на етапі професійного навчання. Отже, мета статті полягає у теоретичному визначенні та емпіричному дослідженні впливу навчального курсу з арт-терапії на підвищення креативності та самоусвідомлення власних психологічних особливостей у студентівпсихологів як суб'єктів особистої життєтворчості.

Виклад основного матеріалу дослідження. Дослідження проводилось на базі ФПСР ОНУ імені I.I. Мечникова. Досліджувана вибірка респондентів складається зі студентів-психологів 3 та 4 курсів факультету психології та соціальної роботи. Загальна кількість респондентів - 69 осіб обох статей. Середній вік респондентів -20 років.

Емпіричне дослідження проводилось у два етапи: до початку навчально-практичного курсу 3 арт-терапії та після нього. Теоретичні методи дослідження містили аналіз, синтез, порівняння та систематизацію сучасних наукових досліджень 3 питань вивчення впливу арт-терапевтичних методів на розвиток креативності та підвищення самоусвідомлення особистості. До емпіричних методів увійшли спостереження, анкетування, бесіда, тест-опитувальник «Самоставлення» (В.В. Столин, С.Р Пантилєєв), методику «САТ» (Ю.Е. Альошина, Л.Я. Гозман, М.В. Загика, М.В. Кроз), а також тест визначення креативності (Е.П. Торенс).

За глобальними шкалами методики САТ на початку дослідження були отримані такі результати. Так, високий бал за шкалою «компетентності» у часі мають $34,8 \%$ респондентів, що свідчить, за інтерпретацією методики, про 
здатність суб' єктів жити сьогоденням, тобто переживати справжній момент свого життя у всій його повноті, а не просто як фатальний наслідок минулого або підготовку до майбутнього «справжнього життя». Саме таке психологічне сприйняття часу суб'єктом свідчить про високий рівень самоактуалізації особистості. Низький бал за шкалою мають $30,4 \%$ респондентів, що означає їх орієнтацію лише на один з відрізків тимчасової шкали (минуле, сьогодення або майбутнє) і (або) дискретне сприйняття свого життєвого шляху. В 34,8\% респондентів - середній рівень за методикою вказує на схильність тримати баланс між протилежними тенденціями. За шкалою «підтримки» 39,1\% респондентів мають високий бал, що вказує на те, що вони незалежні у своїх вчинках, прагнуть керуватися в житті власними цілями, переконаннями, установками й принципами, що, однак, не означає ворожості до оточуючих і конфронтації з груповими нормами. Вони вільні у виборі, не схильні до зовнішнього впливу, спрямовуються з середини. Низький бал за цією шкалою мають $26,1 \%$, що свідчить про високий ступінь залежності, конформності, несамостійності суб'єктів. Середній бал за цією шкалою мають $34,8 \%$ респондентів. За шкалою «ціннісних орієнтацій» високий бал було діагностовано у $47,8 \%$ респондентів, що своєю чергою характеризує високий ступінь їхньої самоактуалізації та постійну орієнтацію на власні цінності, принципи у прийманні важливих життєвих рішень. 34,8\% респондентів мають середній рівень вираженості за цією шкалою, мають схильність до самоактуалізації та частково орієнтуються на власні цінності, принципи у прийманні важливих рішень. У 17,4\% респондентів низький показник за цією шкалою, що вказує на низький ступінь самоактуалізації та нездатність дотримуватись власних принципів. За шкалою «гнучкості поведінки» $34,8 \%$ респондентів мали високий рівень. Це вказує на їх гнучкість у реалізації власних цінностей в поведінці, взаємодії з оточуючими людьми, а також на здатність швидко й адекватно реагувати на мінливу ситуацію. 39,1\% респондентів навпаки мають низький рівень гнучкості поведінки, що вказує на їх ригідність у поведінці, взаємодії з іншими та неможливість адекватно реагувати на мінливі життєві обставини. У 26,1\% респондентів цей показник знаходиться на середньому рівні, що вказує на їхню здатність до гнучкої поведінки. За шкалою «сенситивності» до себе у $39,1 \%$ респондентів було діагностовано високий рівень сенситивності. Вони прислуховуються до власних потреб і побажань, знаходяться у контакті з собою та своїми почуттями; $34,8 \%$ - мають середній рівень сенситивності й здатні до якісної рефлексії. Останні 26,1\% респондентів мають низький рівень сенситивності, нездатні прислуховуватись до власних потреб і побажань, не знаходяться в контакті з собою, не орієнтуються на власні почуття. За шкалою спонтанності високий бал було визначено у $52,2 \%$ респондентів. Це свідчить про можливість не розрахованого заздалегідь способу поведінки, про те, що суб'єкт не боїться поводитися природно та розкуто, демонструвати оточуючим свої емоції. У 13\% респондентів результат за цією шкалою середній, їм частково притаманно демонструвати оточуючим свої емоції та почувати себе розкуто в такі моменти. $34,8 \%$ респондентів мають низький показник спонтанності, що вказує на їхню нездатність до відкритої поведінки та страх бути висміяним, не прийнятим оточуючими. За шкалою «самоповаги» у $56,5 \%$ респондентів діагностовано високий рівень за цією шкалою, що вказує на високий рівень їхньої здатності цінувати власні чесноти, позитивні властивості характеру, поважати себе за них. $34,8 \%$ респондентів мають середній показник вираженості за шкалою самоповаги, що вказує на здатність цінувати деякі власні чесноти й властивості характеру. 8,7\% респондентів мали низький рівень самоповаги, що говорить про їхню нездатність цінувати власні чесноти та неповагу до власних властивостей характеру. За шкалою «самоприйняття» у $47,8 \%$ опитуваних визначено високий рівень. Вони здатні сприймати себе такими, якими вони $€$, миритись із власними слабкостями, помилками та не соромляться виявляти свої слабкості перед друзями. Тоді як $34,8 \%$ респондентів мають низький рівень самоприйняття й не здатні миритись із власними помилками, соромляться своїх слабкостей. Високий бал за шкалою «уявлень про природу людини», визначений у $47,8 \%$ респондентів, свідчить про їхню схильність сприймати природу людини загалом як позитивну й не брати до уваги дихотомії мужності-жіночності, раціональності-емоційності та антагоністичними та непереборними. В 30,4\% респондентів діагностовано середній показник за цією шкалою, а 21,7\% схильні негативно сприймати природу людини й вважають приведені вище дихотомії непереборними. Високий бал за шкалою «синергії» мають $69,6 \%$ респондентів, що визначає їх високу здатність до цілісного сприйняття світу та людей, до розуміння повязаності протилежностей, таких як гра й робота, тілесне та духовне та ін. Й навпаки, 
$30,4 \%$ респондентів показали низький рівень синергії, тож вони не можуть цілісно сприймати світ, гармонічно поєднуючи в ньому протилежне. Середні результати за цією шкалою відсутні. Високий бал за шкалою «прийняття агресії» (39,1\% респондентів) свідчить про здатність студентів-психологів приймати своє роздратування, гнів та агресивність як природнього прояву людини, коли не йде мова про виправдання своєї антисоціальної поведінки. 52,2\% респондентів за цією шкалою мають показник низького рівню, що відображає їхню нездатність витримувати власні емоції, говорить про неприймання власної агресії та гніву як природного, властивого кожній людині компоненту. 8,7\% респондентів мають середній показник за цією шкалою. Шкала «контактна» характеризує високу здатність до швидкого встановлення глибоких і тісних емоційно-насичених контактів 3 людьми у $30,4 \%$ респондентів; 26,4\% респондентів - мають середній рівень контактності і потребують деякого часу для зближення 3 іншими людьми. А 43,5\% респондентів взагалі не схильні до встановлення глибоких і тісних взаємин з іншими людьми. За шкалою пізнавальних потреб, яка визначає ступінь вираженості у суб'єкта прагнення до придбання знань про навколишній світ, у 17,4\% респондентів спостерігається високий рівень. Вони прагнуть пізнавати цей світ 3 усіма його протилежностями й невизначеностями. Середній рівень за цією шкалою мають $21,7 \%$ респондентів, що вказує на середню зацікавленість у навколишньому світі. I 60,9\% респондентів виказали повну незацікавленість у навколишньому світі і в тому, чим вони займаються по життю. Високий рівень за шкалою креативності мають $30,4 \%$ респондентів, що вказує на високу вираженість творчої спрямованості цих особистостей. $47,8 \%$ респондентів виявилися взагалі не творчо-спрямованими, а 21,7\% мали середній рівень вираженості, тож іноді можуть мислити креативно.

На першому етапі дослідження за параметрами методики «Самоставлення» були отримані наступні результати. Так, за шкалою «глобальне самоставлення» було визначено 4,4\% респондентів 3 низьким рівнем глобального самоставлення, які ставляться до себе негативно; 4,4\% мають середній рівень, що характеризує цих людей як тих, хто ставиться до себе позитивно. Високий рівень самоставлення виявлений у $91,2 \%$ респондентів. Тобто переважна кількість випробовуваних переживає яскраво виражене сприятливе ставлення до власного «Я» й відчуває власну цінність, що може вказувати на неадекватну самооцінку респондентів. На проблеми з самооцінкою вказують й показники шкали «самоповага». Не відчувають самоповаги $26,1 \%$ опитаних. Вони не відчувають задоволення собою і не усвідомлюють власної гідності, почуваються неповноцінними, негідними, що чинить негативний вплив на їхне психічне самопочуття й поведінку. Вони ранимі й чутливі до всього, що зачіпає їхню самооцінку. Середньо виражене почуття самоповаги відчувають $26,1 \%$ студентів-психологів. У 47,8\% респондентів почуття власної гідності яскраво виражено. Вони вважають себе здатними, значними, успішними. Вони вірять в себе й у те, що можуть подолати свої недоліки. За шкалою «аутосимпатія» у $8,7 \%$ респондентів показники мають статус «не виражено». Їм властива неповага до себе, емоційна незадоволеність і сором'язливість. У 91,3\% респондентів показник самоповаги має статус «виражений», з них у 73,9\% осіб він виражений дуже яскраво (високий рівень). За шкалою «очікуване відношення від інших» 39,1\% студентів вважають, що вони не викликають симпатію у більшості своїх знайомих. У 43,5\% осіб виражено очікування благодушного до себе ставлення з боку оточуючих. У $17,4 \%$ респондентів ця характеристика яскраво виражена. За шкалою «самоінтерес» респондентів з низьким рівнем самоінтересу виявлено не було. У більшості студентів-психологів ця характеристика яскраво виражена (87\%), це характеризує їх як людей, що зазнають впевненість у своїй цікавості для інших і мають готовність спілкуватися 3 собою «на рівних», не принижуючи себе. $13 \%$ респондентів мають середній рівень самоінтересу. За шкалою «самовпевненість» $21,7 \%$ опитуваних ця характеристика має статус «не виражена», отже, ці люди відчувають неповагу до себе, пов'язану з невпевненістю у своїх можливостях і сумнівом у своїх здібностях. Вони не довіряють своїм рішенням, часто сумніваються у власній здатності долати труднощі й перешкоди, досягати поставленої мети. 78,2\% студентів мають високий і середній рівні відчуття самовпевненості, з них у 56,5\% це відчуття виражено яскраво, що дозволяє судити про цих людей, як про тих, що відчувають виражену самовпевненість. Ці особи поважають себе, задоволені собою, своїми починаннями й досягненнями, відчувають свою компетентність та здатність вирішувати багато життєвих питань. Представники середнього рівня виразності самовпевненості мають властиві високому рівню характеристики, але до відмінної риси можна віднести те, що у 
разі несподіваної появі труднощів у цих людей впевненість у собі знижується, наростають тривога й занепокоєння. За шкалою «ставлення інших» у $30,4 \%$ опитаних виявлено ставлення до себе, як до нездатних викликати повагу в оточення. Схвалення й підтримки від інших ці респонденти не очікують (низький рівень). У представників із середнім ступенем вираженості $(26,1 \%)$ спостерігається виборче сприйняття ставлення оточуючих до себе. На їх погляд, позитивне ставлення оточуючих поширюється лише на певні якості, на певні вчинки; інші особистісні прояви здатні викликати в них роздратування та неприйняття. У респондентів з високим рівнем розвитку показника «ставлення інших» $(43,5 \%)$ можна спостерігати такі характеристики, як відчуття себе прийнятим оточуючими. Вони відчувають в собі товариськість, емоційну відкритість для взаємодії 3 оточенням, легкість встановлення ділових і особистих контактів. За шкалою «самоприйняття» у $21,7 \%$ студентів-психологів $є$ в наявності загальний негативний фон сприйняття себе, схильність сприймати себе надто критично. В них симпатія до себе недостатньо виражена, виявляється епізодично. Лише у 4,4\% осіб, що брали участь у дослідженні, самоприйняття виявлено на середньому рівні, що наділяє їх таким характеристиками, як вибірковість у ставленні до себе, схильність приймати не всі свої достоїнства та критикувати не всі свої недоліки. Респондентам з високим рівнем самоприйняття $(73,9 \%)$ властиво приймати всі сторони свого «Я», приймати себе у всій повноті поведінкових проявів, при цьому загальний фон сприйняття себе залишається позитивним. За шкалою «самокерівництво» $21,7 \%$ респондентів вважають своє «Я» підвладним зовнішнім обставинам і подіям. Механізми саморегуляції в них ослаблені. У 26,1\% опитаних ставлення до свого «Я» залежить від ступеня адаптованості до конкретної ситуації.

У $52,2 \%$ студентів основним джерелом розвитку своєї особистості, регулятором досягнень і успіхів $є$ вони самі. Вони здатні переживати власне «Я» як внутрішній стрижень, який координує та спрямовує всю активність, організовує поведінку і відносини 3 людьми. Такі студенти можуть вдало прогнозувати свої дії та наслідки, що виникають під час контактів з оточуючими. Їм властивий контроль над емоційними реакціями та переживаннями щодо себе. За шкалою «самозвинувачення» $13 \%$ опитаних мають яскраво виражену «негативність» емоцій в адресу власного «Я». Ці студенти перш за все в собі бачать недоліки й готові поставити собі в провину всі свої промахи та невдачі. 21,7\% респондентів-психологів мають виборче ставлення до себе: звинувачення себе за ті чи інші вчинки та дії поєднується 3 виразом гніву, досади на адресу оточуючих. 65,3\% респондентів проявляють тенденцію до заперечення власної провини в конфліктних ситуаціях. Захист власного «Я» здійснюється шляхом звинувачення переважно інших, перенесенням відповідальності на оточуючих за усунення бар'єрів на шляху до досягнення мети. За шкалою «самоінтерес» 8,7\% студентів не відчувають інтересу до себе як до особистості. Більшість респондентів (82,6\% осіб) визнають впевненість у своїй цікавості для інших. За шкалою «саморозуміння» $52,2 \%$ опитаних схильні розуміти свою особистість, свої думки, ідеї, бажання, потреби, що надає їм можливість проживати своє життя більш повно i «бути собою» в максимальному ступені. У $34,8 \%$ респондентів були визначені низькі значення за цим параметром. Вони не в змозі правильно зрозуміти власну особистість i, як наслідок, досягти задоволення собою, що своєю чергою перешкоджає повноцінному розвитку їхньої особистості. $13 \%$ респондентів мають середній результат за цією шкалою.

За методикою Торренса на початку було встановлено, що 23\% студентів мають низький рівень креативності, 70\% респондентів мають середній рівень, й лише в $7 \%$ осіб було визначено високий рівень креативності.

Всі вищевикладені результати стали відправною точкою нашого емпіричного дослідження. Після проведення навчально - практичного курсу 3 арт-терапії нами було здійснено повторне тестування та зроблений порівняльний аналіз отриманих результатів.

Кореляційний аналіз впливу навчального курсу 3 арт-терапії на підвищення креативності та самоусвідомлення власних психологічних особливостей як складників особистісного життєтворчого потенціалу у студентів психологів за U-критерієм Манна-Уітні показав наявність підвищення креативності $\left(\mathrm{U}_{\text {емп }}=882.5\right)$ на рівні значущості $\mathrm{p}<0,01$. Це вказує на підвищення чутливості респондентів до завдань, дефіциту й прогалин знань, прагнення до об'єднання різнопланової інформації. Це також підтримується даними, отриманими за методикою САТ, що проводилась до початку курсу та після його закінчення. Там кореляційний аналіз за Манном-Уітні також показав наявність підвищення креативності $\left(\mathrm{U}_{\text {емп }}=143\right)$ на рівні значущості $\mathrm{p}<0,01$ та підвищення за шкалою 
пізнавальні потреби $\left(\mathrm{U}_{\text {емп }}=150,5\right)$ на тому ж рівні значущості. Крім того, аналіз змін, детермінованих практичною частиною курсу з інтегративної арт-терапії, показав наявність значущого підвищення за таким параметром методики САТ, як сензитивність $\left(\mathrm{U}_{\text {емп }}=148\right)$ на рівні значущості $\mathrm{p}<0,01$, що своєю чергою вказує на те, що респонденти почали більше віддавати собі звіт у своїх потребах і почуттях за умов покращення їхнього відчування та рефлексії. За показником «спонтанність» результати $U$ емпіричного опинилися у зоні невизначеності $\left(\mathrm{U}_{\text {емп }}=172\right)$. Як відомо, цей показник вимірює здатність індивіда спонтанно й безпосередньо виражати свої почуття. Це зумовлено, на нашу думку, тим, що навчальний університетській формат роботи не передбачає повністю захищеного арт-терапевтичного простору. Отже, студентам було складно поводити себе природно й розкуто та демонструвати оточуючим власні емоції. Але опитування наприкінці курсу визначило, що арт-терапевтичний формат роботи, навіть у закладі вищої освіти, надав їм можливість не тільки виразити та усвідомити власні емоції та почуття, а й стати більш толерантними до емоцій інших та підтримуючими. Це підтверджує й підвищення показника «прийняття агресії» $\left(\mathrm{U}_{\mathrm{eмп}}=167\right)$ на рівні значущості $\mathrm{p}<0,01$. А також про це говорять такі висловлювання студентів: «За час арт-терапевтичного курсу ми зрозуміли, що будь-які емоції - це «нормально», прояв цих емоцій - це частина життя й без усвідомлення цього, без вираження того, що мі відчуваємо, не можна відповісти на питання - хто ми є...», «Більше за все було складно під час вербалізації моїх почуттів, фізичних та емоційних відчуттів. Також важко було працювати з негативними емоціями, але наприкінці занять ці відчуття завжди змінялись на легкість та гармонію...», «Позитивний досвід було отримано від проголошення процесу та результату моєї праці, хоча й був страх відкрити для себе й оточуючих те, що довгий час було мною витіснене...», «Важко ділитись таємним, коли так уважно прислуховуються...», «Ми більше зблизились за час курсу, ніж за три роки до нього». Але попри більшу усвідомленість щодо власних почуттів, студенти не спрямовані на швидке встановлення глибоких i тісних емоційно-насичених контактів 3 людьми, про це говорять показники за шкалою «контактності», де $\mathrm{U}_{\text {емп }}=216,5$ знаходиться у зоні незначності. Це вказує на те, що студентам потрібен час на додаткове відпрацьовування вмінь упоратися 3 власними емоціями та їхнє адекватне вираження в навколишньому соціальному середовищі. Показники за шкалами самоприйняття $\left(\mathrm{U}_{\mathrm{eмп}}=184\right)$, підтримки $\left(\mathrm{U}_{\text {емп }}=162\right)$ та «компетентності у часі» $\left(\mathrm{U}_{\text {емп }}=191\right)$ опинилися у зоні невизначеності, що, на нашу думку, було результатом, який очікувався, оскільки курс інтегративної арт-терапії в навчальному закладі все ж таки передбачає отримування студентами загальних знань 3 арт-терапії та набуття на підставі власного досвіду практичних вмінь, які б вони могли надалі використовувати у власній професійній діяльності, а не особистісну або групову психотерапію. Проте переміщення цих показників у зону невизначеності також може вказувати на підвищення рівня самоусвідомлення у студентів за цими параметрами. Крім того, потрібно враховувати, що відпрацьовування отриманих знань також потребує самостійної роботи студентів, де отримані знання змогли б стати самодостатніми навичками, що пройшли закріплення в часі та просторі існування особистості. За параметрами «ціннісні орієнтації», «гнучкість поведінки», «самоповаги», «уявлення про природу людини», «синергія» суттєвих змін визначено не було, хоч отримані результати показали наявність позитивної динаміки. Показники середньогрупового суб'єкту за загальним рівнем самоактуалізації до початку та після закінчення навчального курсу 3 інтегративної арт-терапії також показали наявність позитивної динаміки у групах студентівпсихологів.

Стосовно методики самоставлення на другому етапі дослідження були отримані такі результати: за параметром «глобальне самоставлення» відбулося зниження високих балів та підвищення середніх значень (на рівні значущості $\mathrm{p}<0,01 \mathrm{U}_{\text {емп }}=127,5$. Також відбулося підвищення середніх значень за шкалою самозвинувачення $\mathrm{U}_{\text {емп }}=169.5$ при рівні значущості $\mathrm{p}<0,01$. Все це, на наш погляд, також може свідчити про підвищення самоусвідомлення студентів, про розвиток їхніх рефлексивних здібностей щодо особистісних особливостей. Що стосується параметру «аутосимпатія», то тут також відбулося підвищення середнього рівня при зниженні високого, проте, попри деякі зміни, $\mathrm{U}_{\text {емп }}(198)$ знаходиться в зоні незначущості, що може говорити про так званий «плаваючий» рівень самооцінки респондентів, його залежність від оточуючого середовища. Показники $\mathrm{U}_{\text {емп }}$ за параметрами «самоприйняття», «самокерівництво» та «саморозуміння» опинилися в зоні невизначеності. Значущих змін за іншими параметрами визначено не було. 
Щодо визначення рівня креативності за методикою Торенса на другому етапі дослідження було встановлено, що низький рівень креативності мають 7\% респондентів, $62 \%$ студентів психологів мають середній рівень, й $33 \%$ осіб здатні проявляти високий рівень креативності. На розвиток креативності студентів й значущість цих змін вказує показник $\mathrm{U}_{\text {емп }}=942.5$ на рівні значущості $\mathrm{p}<0,01$, що свідчить про підвищення в респондентів здатності висувати ідеї, які відрізняються від очевидних, загальновідомих, загальноприйнятих, банальних чи твердо встановлених, про підняття їхньої інтелектуальної активності, що своєю чергою підтверджується даними, отриманими на другому етапі дослідження за методикою САТ.

Аналіз практичної значущості курсу 3 арттерапії за висловлюваннями студентів-психологів виявив iii 4 основні напрями: «повернення до себе» та самоприйняття (30,4\% респондентів), підвищення сенситивності та покращення міжособистісної чуттєвості (27,5\%), підвищення креа- тивності (16\%), ефективні інструменти професійної діяльності $(26,1 \%)$.

Висновки 3 проведеного дослідження. Проведене дослідження вказує на ефективність впливу навчально-практичного курсу з арт-терапії на підвищення рівня креативності та на самоусвідомлення власних психологічних особливостей студентівпсихологів. Вивчення теорії з арт-терапії, практичне опрацювання вправ у навчальній групі та самостійне опрацьовування арт-терапевтичних засобів саморегуляції сприяють не тільки покращенню психоемоційного стану студентів та підвищенню їхнього власного самоусвідомлення, але й впливають на розвиток творчих здібностей, на більш вільне саморозкриття, на придбання навичок продуктивної міжособистісної взаємодії й на усвідомлення можливості керувати своїми психічними процесами й станами як свідомих суб' єктів власної життєтворчості. Саме формування особистості, здатної до власної життєтворчості, $є$ сьогодні основним завданням, що постає перед закладами вищої освіти, які здійснюють професійну підготовку майбутніх психологів-фахівців.

\section{Список літератури:}

1. Артюхіна Н.В Базові складові життєтворчості особистості. Збірник наукових праць Теорія і практика сучасної психологіï. Класичний приватний університет, м. Запоріжжя, Т. 1, № 2. 2019 рік. С. 10-16.

2. Інжиєвська Л.А. Особливості арт-технологій в підготовці майбутніх психологів. Вісник Одеського національного університету. Серія: Психологія. 2013. Т. 18, Вип. 4. С. 106-113.

3. Колошина Т.Ю. Арт-терапия: методические рекомендации. Москва. Изд-во Института психотерапии и клинической психологии. 2002. 84 с.

4. Леонтьев Д.А. Жизнетворчество как практика расширения жизненного мира. 1-я Всероссийская научно-практическая конференщия по экзистенщиальной психологии: материаль сообщений / под редакцией Д.А. Леонтьева, Е.С. Мазур, А.И. Сосланда. Москва. 2001. С. 100-109.

5. Подкоритова Л.О. Застосування арт-терапії для самопізнання студентів соціономічної сфери. Актуальні проблеми психологї : Зб. наук. Пращь. Інститут психології імені Г.С. Костюка НАПН України. Загальна психологія. Історична психологія. Етнічна психологія. Вип. 7. К. 2015. Том IX. С. 201-208.

\section{Artiukhina N.V., Simovonyk A.I. THE INFLUENCE OF THE TRAINING COURSE ON ART THERAPY ON INCREASING CREATIVITY AND SELF-AWARENESS OF THEIR OWN PSYCHOLOGICAL CHARACTERISTICS IN STUDENTS-PSYCHOLOGISTS}

The article presents a study of the art therapy course impact on increasing students-psychologists' creativity and self-awareness psychological characteristics, as subjects of their own creativity. It is pointed out that the tasks of personal development, increase of self-awareness, moral responsibility and activation of one's own life-creating potential are becoming more and more urgent. Therefore, the training of a future psychologist should be aimed not only at obtaining a certain professional qualification in the relevant field, but also at improving the socialization of the modern student and harmonizing his interaction with himself and reality. It is also pointed out that at the stage of higher psychological education there is a growing interest in such educational technologies and methods that can have a safe and positive impact on maintaining mental health and personal development of students, and later become effective tools for their professional activities. It is emphasized that such educational technologies include art therapy, in the study of which students gain the necessary theoretical and practical experience on safe, positive impact on mental and social health, as well as on the psychological correction of emotional states and activation of internal creative potential of man through art. It is pointed out that the study of the theory of art therapy, practical development of exercises in the study group and self-development of art-therapeutic means of self-regulation not only improve students' psycho-emotional state and increase their own self-awareness, but also influence the development of creative 
abilities, to acquire the skills of productive interpersonal interaction and to realize the ability to control their mental processes and states, as conscious subjects of their own life. The formation of a person capable of their own life is the main task today, which faces higher education institutions that provide training for future psychologists - specialists.

Key words: personality, the subject of his own life-creativity, self-awareness, art therapy, studying, creativity, self-actualization. 